\title{
ACROSS-SHIFT CHANGES OF EXHALED NITRIC OXIDE AND SPIROMETRIC INDICES AMONG COTTON TEXTILE WORKERS
}

\author{
SEYED JALIL MIRMOHAMMADI ${ }^{1}$, AMIR HOUSHANG MEHRPARVAR ${ }^{1,2}$, SARA SAFAEI ${ }^{1}$, \\ MOJAHEDE SALMANI NODOUSHAN ${ }^{1}$, and MONA TORAB JAHROMI ${ }^{1}$ \\ ${ }^{1}$ Shahid Sadoughi University of Medical Sciences, Yazd, Iran \\ Department of Occupational Medicine \\ ${ }^{2}$ Industrial Diseases Research Center, Yazd, Iran
}

\begin{abstract}
Objectives: For the purpose of evaluation of exhaled NO as an index of airway inflammation, we assessed changes in fractional exhaled NO (FeNO) across a work shift and its relationship with respiratory complaints. Material and Methods: Chronic and work-aggravated respiratory complaints were assessed using a questionnaire in 89 male textile workers. FeNO and spirometry were performed before and after a work shift and all the changes were registered. Results: A significant increase in FeNO after a work shift was observed. Post-shift FeNO was significantly higher among the subjects with chronic respiratory complaints. There was an obvious decrease in FVC, and $\mathrm{FEV}_{1}$ after a work shift; however, we couldn't find a significant relationship between changes in respiratory parameters and concentration of inhalable dusts. Conclusions: FeNO increase after a work shift along with pulmonary function decrement and higher post-shift FeNO among subjects with respiratory complaints makes across-shift FeNO a non-invasive test for assessment of airway hyper-responsiveness in textile workers.
\end{abstract}

Key words:

Spirometry, Across shift, Exhaled nitric oxide, Textile industry

\section{INTRODUCTION}

Textile industry is one of the oldest and largest industries in the world. Over 60 million people all over the world work in the textile or clothing industry [1]. Textile workers are exposed to various kinds of dust. In the case of textile workers, inhalation of cotton dust is associated with respiratory complaints, acute and chronic loss of pulmonary function and airway inflammation [2]. Acute airway response is defined by across-shift decrease in forced expiratory volume in $1 \mathrm{~s}\left(\mathrm{FEV}_{1}\right)$ with or without such respiratory complaints as chest tightness, cough, dyspnea and wheezing [2-5]. Byssinosis was described as the onset of cough and chest tightness among textile workers in the first days of work along with pulmonary function decrement [6]. Besides, chronic obstruction of airways in workers exposed to cotton dust is more frequent than in general population [7-11]. Various mechanisms have been proposed as a reason for pulmonary function loss among textile workers, and inflammation of airways after inhalation of cotton dust containing endotoxin is one of the oldest proposed mechanisms [12,13].

Received: February 10, 2014. Accepted: June 16, 2014.

Corresponding author: S. Safaei, Shahid Rahnamoun Hospital, Department of Occupational Medicine, Farrokhi 2, Yazd 8913893111, Iran (e-mail: sr.safaie@yahoo.com). 
The degree of this inflammation depends on exposure duration, concentration of cotton dust, grade of cotton fibers, and the presence and amount of endotoxin, and other microbial contaminations in cotton dust [14-16].

For assessment of airway inflammation, non-invasive methods such as Exhaled Breath Condensate (EBC), induced sputum, fractional exhaled nitric oxide (FeNO) can be used, but there is no consensus on the use of these methods for evaluation of occupational respiratory diseases [17]. Many studies have shown an increase in FeNO among subjects with airway hyper-responsiveness [18-22], but only few studies have assessed changes of this index for detection of occupational asthma [23-26]. In a study on potroom workers, Lund et al. have found significantly higher FeNO concentrations than in a control group, and this measure was also higher among those with asthmatic symptoms [23]. In another study, which was conducted for assessment of occupational asthma in health care workers, farmers and bakers, the authors have found a significant increase in FeNO after a specific inhalation test with relevant allergens [24].

Studies have shown an increase in respiratory complaints and decrease in spirometric parameters among cotton workers, but the effect of cotton dust inhalation on acrossshift FeNO changes and its relationship with respiratory complaints is not fully understood. Therefore, in this study we assessed the across-shift changes in FeNO and its relationship with work-related respiratory complaints among cotton textile workers.

\section{MATERIAL AND METHODS}

\section{Study design}

The study was performed during annual examinations of workers in January, and February 2013 in Yazd, a central province of Iran. The study was conducted in one of the largest textile plants in Yazd. Each day, 5 workers were assessed before and after their work shift (6 a.m. and 2 p.m.).
In order to reduce the effect of the first day of week reduction in pulmonary indices, the workers were assessed at least $24 \mathrm{~h}$ after their last shift during the week. Concurrently, inhalable dust and respirable dust were evaluated in the plant. Fractional exhaled NO and spirometric parameters were measured before and after a work shift and changes in both tests were then compared.

The study was approved by the ethics committee of the Shahid Sadoughi University of Medical Sciences. An informed consent was obtained from all the study participants.

\section{Participants}

Of 106 male workers of a spinning factory, working in opening, carding, and doubling units, 17 subjects were excluded from the study (4 due to a recent respiratory infection or inability to perform acceptable spirometry maneuvers, and 13 due to smoking), so finally 89 male, nonsmoking workers were assessed. None of the workers used respiratory protection regularly.

\section{Cumulative dust exposure}

Personal exposure to inhalable (aerodynamic diameter of less than $100 \mu \mathrm{m}$ ) and respirable (aerodynamic diameter of less than $4 \mu \mathrm{m}$ ) dust was sampled using IOM (SKC-SP690, UK) and Cassella (APEX, USA) sampling pumps, respectively. Three samplings were performed on each work post and the arithmetic mean was used as the final result.

\section{Respiratory symptoms evaluation}

Respiratory complaints were assessed using "modified recommended respiratory disease questionnaires for use with adults and children in epidemiological research" [27]. The workers were asked to answer "yes" or "no" to each question. Information concerning periods of cough, sputum, dyspnea, wheezing and their aggravation during a work shift, documented history of such respiratory diseases as allergic rhinitis, smoking, and occupational history were recorded using the aforementioned questionnaire. 
Smokers were assessed by pack/years of smoking (i.e., the number of cigarettes smoked per day divided by 20 and multiplied by years of smoking). Those who smoked at least 0.5 pack-years were considered as smokers and were excluded from the study. Questionnaires were filled by an occupational medicine resident.

\section{FeNO measurement}

FeNO was measured before spirometry, by a different person in all non-smokers using a portable electrochemistrybased device (NObreath ${ }^{\circledR}$, Bedfont Scientific Ltd., UK). All tests were performed according to the guidelines of American Thoracic Society/European Respiratory Society (ATS/ERS) [28,29]. Results were reported in part per billion ( $\mathrm{ppb}$ ). The subjects were asked to perform expiration in a sitting position, for $10 \mathrm{~s}$ with a constant flow $(50 \mathrm{ml} / \mathrm{s})$ and pressure $\left(10 \mathrm{~cm} \mathrm{H}_{2} \mathrm{O}\right)$. The situation was controlled automatically by the device. Measurements were repeated until we obtained at least 2 acceptable maneuvers with $4 \mathrm{ppb}$ difference in FeNO at most. The mean of the 2 tests was reported as the final result. The measurements were repeated after the work shift $(8 \mathrm{~h})$. The subjects were asked to avoid large meals and heavy exercise such as stair climbing and heavy lifting $1 \mathrm{~h}$ before the test.

\section{Lung function assessment}

Spirometry was performed before and after a work shift by spirolab III (MIR, Italy). Forced vital capacity (FVC), forced expiratory volume in $1 \mathrm{~s}\left(\mathrm{FEV}_{1}\right)$, peak expiratory flow (PEF), and forced expiratory flow between $25 \%$ to $75 \%$ of $\mathrm{FVC}\left(\mathrm{FEF}_{25-75 \%}\right)$, were measured in accordance with ATS/ERS guidelines [30]. All the tests were performed under standardized conditions at body temperature and ambient pressure saturated with water vapor, with the subject in a sitting position and using a nose clip. All the subjects performed spirometry under the same conditions. The highest of the 3 technically acceptable recordings was used.

\section{Statistics}

Data were analyzed by the use of IBM SPSS Statistics 19 (IBM Corp., North Castle, NY, Windows). Assessment of the frequency of data was performed using descriptive statistics. Kolmogorov-Smirnov test was used to test the normality of data. Continuous quantitative data were analyzed using the Student's T test and mean respiratory parameters before and after a work shift were compared using the paired $\mathrm{T}$ test. The frequency of respiratory complaints among different work posts was compared using the $\mathrm{Chi}^{2}$ test. Pearson's correlation test was used to assess association between dust concentration and changes in pulmonary function parameters and correlation between changes in FeNO and pulmonary function parameters.

\section{RESULTS}

\section{Characteristics of participants}

Demographic information about the subjects is presented in Table 1. All the participants were males, aged 18-52 with work experience of 2-300 months. Among all, 8 subjects $(8.9 \%)$ had a positive history of documented respiratory diseases.

Table 1. Demographic characteristics of the study group

\begin{tabular}{ll}
\hline \multicolumn{1}{c}{ Variable } & \multicolumn{1}{c}{$\begin{array}{c}\text { Respondents } \\
(\mathrm{N}=89)\end{array}$} \\
\hline Age (years) [AM \pm SD (range)] & $30 \pm 7(18-52)$ \\
Work in textile industry (months) & $101 \pm 92(2-300)$ \\
$\quad[$ AM \pm SD (range) & \\
Respiratory disease [n (\%)] & \\
asthma & $1(1.1)$ \\
pneumonia & $1(1.1)$ \\
allergic rhinitis & $4(4.5)$ \\
sinusitis & $2(2.2)$ \\
\hline
\end{tabular}

$\mathrm{AM}$ - arithmetic mean; $\mathrm{SD}$ - standard deviation.

Concentration of dust in all parts of the spinning unit was higher than the permissible exposure limit presented by occupational safety and health association [31]. The 
highest concentration of inhalable $\left(12.9 \mathrm{mg} / \mathrm{m}^{3}\right)$ and respirable $\left(5.2 \mathrm{mg} / \mathrm{m}^{3}\right)$ dust was observed in the opening unit, and the difference in the concentration among different parts of the plant was significant $(\mathrm{p}<0.001)$.

\section{Chronic and work-related respiratory symptoms}

Among 89 subjects, 23 (25.8\%) suffered from chronic respiratory symptoms and 17 (19.1\%) complained of aggravation of their respiratory symptoms during their work shift. Among those 17, one subject with asthma was previously diagnosed. We couldn't find a statistically significant relationship between concentration of dust and work-aggravated respiratory complaints ( $p=0.145$ and $p=0.283$, for inhalable dust and respirable dust, respectively). Frequency of work aggravated respiratory complaints was not significantly different among various work posts $(p=0.167)$. There was a significant relationship between work experience of more than 15 years and the frequency of subjects with work-aggravated respiratory complaints $(p=0.045)$. Table 2 shows concentration of dust and the frequency of respiratory complaints with respect to the work post.

\section{FeNO}

The mean FeNO was significantly increased after a work shift (7.69 ppb before and 10.65 after, $p<0.001$ ). Mean post-shift FeNO among the subjects with respiratory complaints was significantly higher than among those without any work-aggravated respiratory complaints (14.88 vs. 9.65, $\mathrm{p}=0.011$ ), but the mean pre-shift FeNO between the 2 groups was not significantly different (8.28 vs. $7.33, p=0.166$ ). Only in 3 subjects post-shift FeNO was more than $25 \mathrm{ppb}$ and all of them suffered from work- aggravated respiratory complaints.

There was no significant correlation between concentration of dust and across-shift FeNO change ( $p=0.35$, $p=0.37$ for inhalable and respirable dust, respectively).

\section{Lung function assessment}

Mean $\mathrm{FEV}_{1}, \mathrm{FVC}$, and $\mathrm{FEF}_{25-75 \%}$ were significantly decreased after a work shift. We couldn't find a significant relationship between concentration of dust and acrossshift changes in spirometric parameters. Respiratory complaints were significantly related to across-shift FVC and $\mathrm{FEV}_{1}$ change ( $\mathrm{p}=0.044$ and $\mathrm{p}=0.028$, respectively). There was a significant correlation between work experience and across-shift changes in $\mathrm{FVC}, \mathrm{FEV}_{1}$ and $\mathrm{FEF}_{25-75 \%}$ ( $p=0.041, p=0.008$ and $p=0.031$, respectively). Significant correlations were not observed between mean FeNO changes and spirometric parameters. Table 3 presents lung function and FeNO levels of all the workers and the workers with work-aggravated respiratory complaints and without respiratory complaints.

Table 2. Concentration of dust and frequency of respiratory complaints regarding the work post

\begin{tabular}{|c|c|c|c|}
\hline \multirow[t]{2}{*}{$\begin{array}{l}\text { Work-aggravated } \\
\text { respiratory complaints } \\
\text { (n) }\end{array}$} & \multicolumn{2}{|c|}{$\begin{array}{l}\text { Dust concentration } \\
\qquad\left(\mathrm{mg} / \mathrm{m}^{3}\right) \\
\mathrm{AM} \pm \mathrm{SD} \\
\text { (range) }\end{array}$} & \multirow[t]{2}{*}{$\begin{array}{c}\text { Work post } \\
{[\mathrm{n}(\%)]}\end{array}$} \\
\hline & respirable & inhalable & \\
\hline 6 & $\begin{array}{c}4.1 \pm 1.1 \\
(2.6-7.9)\end{array}$ & $\begin{array}{l}11.9 \pm 2.7 \\
(6.2-21.2)\end{array}$ & $\begin{array}{c}\text { doubling } \\
31(34.8 \%)\end{array}$ \\
\hline 9 & $\begin{array}{c}5.2 \pm 0.8 \\
(3.1-7.7)\end{array}$ & $\begin{array}{l}12.9 \pm 2.4 \\
(7.1-19.3)\end{array}$ & $\begin{array}{c}\text { opening } \\
30(33.7 \%)\end{array}$ \\
\hline 2 & $\begin{array}{c}3.4 \pm 0.6 \\
(2.3-4.8)\end{array}$ & $\begin{array}{l}11.5 \pm 1.9 \\
(9.4-13.9)\end{array}$ & $\begin{array}{c}\text { carding } \\
28(31.4 \%)\end{array}$ \\
\hline
\end{tabular}

Abbreviations as in Table 1. 
Table 3. Lung function and FeNO levels of all the workers and workers with work-aggravated respiratory complaints and without respiratory complaints

\begin{tabular}{|c|c|c|c|}
\hline Parameter & $\begin{array}{c}\text { All workers } \\
\text { AM (95\% CI) }\end{array}$ & $\begin{array}{l}\text { With respiratory complaints } \\
\qquad \begin{array}{c}(\mathrm{N}=17) \\
\mathrm{AM}(95 \% \mathrm{CI})\end{array}\end{array}$ & $\begin{array}{l}\text { Without respiratory complaints } \\
\qquad(\mathrm{N}=72) \\
\operatorname{AM}(95 \% \mathrm{CI})\end{array}$ \\
\hline \multicolumn{4}{|l|}{ FeNO (ppb) } \\
\hline pre-shift & $7.69(6.42-8.95)$ & $8.28(4.38-13.09)$ & $7.33(5.97-8.20)$ \\
\hline post-shift & $10.65(9.03-12.27)$ & $14.88(8.66-21.11)$ & $9.65(8.28-11.05)$ \\
\hline cross-shift & $2.96(1.50-4.41)$ & $6.60(4.33-8.86)$ & $2.32(3.67-5.70)$ \\
\hline $\mathrm{p}$ & $<0.001$ & $<0.001$ & 0.054 \\
\hline \multicolumn{4}{|l|}{$\mathrm{FEV}_{1}(\mathrm{l})$} \\
\hline pre-shift & $3.77(3.65-3.89)$ & $3.71(3.32-4.43)$ & $3.78(3.66-3.91)$ \\
\hline post-shift & $3.72(3.59-3.85)$ & $3.60(3.21-3.99)$ & $3.75(3.62-3.88)$ \\
\hline cross-shift & $-0.05(-0.09-(-0.01))$ & $-0.11(-0.22-(-0.007))$ & $-0.03(-0.08-0.01)$ \\
\hline $\mathrm{p}$ & 0.039 & 0.029 & 0.213 \\
\hline \multicolumn{4}{|l|}{ FVC (l) } \\
\hline pre-shift & $4.52(4.37-4.66)$ & $4.62(4.19-5.02)$ & $4.49(4.34-4.64)$ \\
\hline post-shift & $4.39(4.25-4.53)$ & $4.27(3.92-4.61)$ & $4.41(4.26-4.57)$ \\
\hline cross-shift & $-0.13(-0.19-(-0.06))$ & $-0.35(-0.56-(-0.14))$ & $-0.07(-0.14-(-0.01))$ \\
\hline $\mathrm{p}$ & $<0.001$ & 0.003 & 0.017 \\
\hline \multicolumn{4}{|l|}{$\mathrm{FEV}_{1} / \mathrm{FVC}(\%)$} \\
\hline pre-shift & $84.05(82.6-85.4)$ & $80.50(75.89-85.11)$ & $84.8(83.4-86.3)$ \\
\hline post-shift & $85.21(83.6-86.7)$ & $83.94(78.22-89.67)$ & $85.5(84.0-87.0)$ \\
\hline cross-shift & $1.15(0.37-1.93)$ & $3.44(0.04-6.83)$ & $0.61(0.05-1.17)$ \\
\hline $\mathrm{p}$ & $<0.001$ & 0.047 & 0.031 \\
\hline \multicolumn{4}{|l|}{$\mathrm{FEF}_{25-75 \%}(1 / \mathrm{s})$} \\
\hline pre-shift & $4.18(3.94-4.42)$ & $3.88(3.13-4.63)$ & $4.25(4.01-4.49)$ \\
\hline post-shift & $4.01(3.74-4.28)$ & $3.51(2.76-4.27)$ & $4.13(3.84-4.41)$ \\
\hline cross-shift & $-0.17(-0.33-(-0.004))$ & $-0.36(-0.64-(-0.09))$ & $-0.12(1.02-4.11)$ \\
\hline $\mathrm{p}$ & 0.045 & 0.013 & 0.213 \\
\hline \multicolumn{4}{|l|}{ PEF (1/s) } \\
\hline pre-shift & $8.16(7.83-8.48)$ & $7.87(6.98-8.76)$ & $8.22(7.88-8.57)$ \\
\hline post-shift & $8.28(7.96-8.60)$ & $8.07(7.29-8.86)$ & $8.33(7.97-8.69)$ \\
\hline cross-shift & $0.12(-0.81-0.32)$ & $0.20(-0.18-0.60)$ & $0.10(-0.13-0.34)$ \\
\hline $\mathrm{p}$ & 0.235 & 0.285 & 0.391 \\
\hline
\end{tabular}

$\mathrm{AM}$ - arithmetic mean; FeNO - fractional exhaled nitric oxide; ppb - part per billion; $\mathrm{FEV}_{1}$ - forced expiratory volume in $1 \mathrm{~s}$; FVC - forced vital capacity; $\mathrm{FEF}_{25-75 \%}$ - forced expiratory flow between $25 \%$ to $75 \%$; $\mathrm{PEF}$ - peak expiratory flow; CI - confidence interval. 


\section{DISCUSSION}

Increased FeNO and decreased spirometric parameters in textile workers after a work shift show a probable inflammation of airways after exposure to organic cotton dust. Although pre-shift FeNO was not significantly different between the subjects with and without respiratory complaints, post-shift FeNO among the workers with work-aggravated respiratory complaints was significantly higher than among those without such complaints. Additionally, the study showed a relationship between work experience and the frequency of work-aggravated respiratory complaints, but there wasn't a relationship between concentration of cotton dust and changes in pulmonary function tests. We couldn't find a significant relationship between changes of mean FeNO and spirometric parameters.

The observed change in $\mathrm{FEV}_{1}, \mathrm{FVC}$ and $\mathrm{FEF}_{25-75 \%}$ parameters was consistent with the study conducted by Mandryk et al. [32], which was carried out among Australian wood workers. The authors have reported significant decreases in $\mathrm{FEV}_{1}$ but also significant decreases in $\mathrm{FEV}_{1} / \mathrm{FVC}, \mathrm{FEF}_{25-75 \%}$ and $\mathrm{PEF}$ among woodworkers after exposure to wood dust, which was also higher than in the control group [32].

Acute response after exposure to cotton dust was also assessed by Sepulveda et al. They have found that exposure to cotton dust significantly decreased spirometric parameters, especially in atopic subjects [33].

Sandstrom et al. have compared cellular profile and fibronectin of bronchoalveolar lavage fluid among healthy individuals before and after inhalation of lipopolysaccharide. They have proposed that significant increase of neutrophils, lymphocytes and fibronectin after inhalation of LPS supports the possible role of bacterial endotoxin in airway inflammation and pulmonary function decrement due to exposure to organic dust in such occupations as cotton mill workers. Pulmonary function decrement in the current study along with the increased FeNO after a work shift is probably a non-invasive index of airway inflammation, which is consistent with the results of the study conducted by Sandstorm et al [34].

In the study on sewage workers, FeNO was not significantly higher in the exposed subjects than it was in the control group, although their sample size was too small [35]. Baur et al. in the study on health care workers (HCWs), have assessed change in FeNO after exposure to latex. One hour after exposure to latex, FeNO was significantly increased in both sensitized and nonsensitized subjects, but after $24 \mathrm{~h}$ this increase remained only in the sensitized subjects. This study has proposed assessment of across-shift changes of FeNO as a screening test in HCWs [36].

The across-shift increase in FeNO following exposure to cotton dust was consistent with the results of a study on coffee-curing workers. The authors have found that mean FeNO was significantly higher in the workers exposed to coffee dust. In this study the relationship between concentration of dust and FeNO was not evaluated [37]. In another study on the workers of a coffee factory, the relationship between respiratory complaints and concentration of dust was evaluated in addition to the measurement of dust and endotoxin concentrations [38]. The study has failed to show a significant difference between the case and control groups, although coffee workers had more respiratory complaints than the control subjects. In this study, cumulative exposure to endotoxin was significantly related to a decrease in spirometric parameters, but in the current study we couldn't find a significant relationship between concentration of cotton dust and across-shift changes in pulmonary function.

To the best of our knowledge, this was the 1st study on FeNO before and after a work shift in textile industry. Considering the large number of textile industries in the world and frequent respiratory complaints in textile workers, the result of this study may help diagnose respiratory diseases at an early stage. 


\section{Our study had some limitations}

There exists a probable circadian rhythm of FeNO production. We measured FeNO at 6 a.m. and 2 p.m., so circadian changes may have affected the observed changes. Some studies have shown these circadian changes [39], although some others, such as Antosova et al., have shown that FeNO levels are similar at 6 a.m. and 2 p.m. So this circadian rhythm seems to have had a minimal effect in our study [40-42].

We didn't assess the history of atopy in our subjects. Atopy as a confounding factor, can affect the results of FeNO [43]. We had to assess only 5 workers in each shift in order not to interfere with the production of the plant, so some changes in respiratory exposures of the workers during the study period is possible. This may have affected the relationship between spirometric parameters and concentration of dust. We couldn't measure the level of endotoxin and few numbers of dust measurements were performed.

The main limitation of our study is the lack of a control group - we couldn't compare FeNO between the individuals with and without exposure to cotton dust. But due to the cross-shift design of our study each person acts as their own control. This design helps to minimize the influence of other confounding factors of FeNO such as age, sex, food, etc.

This study originated from a residency thesis in occupational medicine in Shahid Sadoughi University of medical sciences.

\section{CONCLUSION}

Considering the significant across-shift changes in FeNO among textile workers along with pulmonary function loss and the higher level of post-shift FeNO in the workers with work aggravated respiratory complaints in the current study, it is possible to consider the across-shift FeNO as a non-invasive method for evaluation of airway hyper-responsiveness among workers with occupational respiratory exposures. Nevertheless, other studies with inclusion of a control group are needed to prove this hypothesis.

\section{ACKNOWLEDGMENTS}

The authors are grateful to all the participants and the management in charge of the participating factory.

\section{REFERENCES}

1. Forstater M. Implications of the global financial and economic crisis on the textile and clothing sector. In: Sectoral coverage of the global economic crisis 2009. Geneva: International Labour Organization; 2009.

2. Wang XR, Zhanget HX, Sun BX, Dai HL, Hang JQ, Eisen EA, et al. A 20-year follow-up study on chronic respiratory effects of exposure to cotton dust. Eur Respir J. 2005;26:881-6, http://dx.doi.org/10.1183/09031936.05.00125604.

3. Zuskin EE, Valić FF. Change in the respiratory response to coarse cotton dust over a ten-year period. Am Rev Respir Dis. 1975;112:417-42.

4. Schilling RS, Hughes JP, Dingwall-Fordyce I, Gilson JC. An epidemiological study of byssinosis among Lancashire cotton workers. Br J Ind Med. 1955;12:217-27.

5. Imbus H, Suh M. Byssinosis: A study of 10133 textile workers. Arch Environ Health. 1973;26:183-91, http://dx.doi. org/10.1080/00039896.1973.10666253.

6. Schilling RSF. Byssinosis in cotton and other textile workers. Lancet. 1956;2:261-5, http://dx.doi.org/10.1016/S01406736(56)92077-3.

7. Bouhuys A, Shoenberg JB, Beck GJ, Schilling RSF. Epidemiology of chronic lung disease in a cotton mill community. Lung. 1977;154:167-86, http://dx.doi.org/10.1007/BF02713532.

8. Beck GJ, Schachter EN, Maunder LR, Schilling RS. A prospective study of chronic lung disease in cotton textile workers. Ann Intern Med. 1982;97:645-51, http://dx.doi. org/10.7326/0003-4819-97-5-645. 
9. Glindmeyer HW, Lefante JJ, Jones RN, Rando RJ, Kader HA, Weill H. Exposure-related declines in the lung function of cotton textile workers. Relationship to current workplace standards. Am Rev Respir Dis. 1991;144:675-83, http://dx.doi.org/10.1164/ajrccm/144.3_Pt_1.675.

10. Bouhuys A, Zuskin E. Chronic respiratory disease in hemp workers. A follow-up study, 1967-1974. Ann Intern Med. 1976;84(4):398-405, http://dx.doi.org/10.7326/0003-48 19-84-4-398.

11. Christiani D, Ye T, Zhang S, Wegman DH, Eisen EA, Ryan L, et al. Cotton dust and endotoxin exposure and long-term decline in lung function: Results of a longitudinal study. Am J Ind Med. 1999;35(4):321-31, http://dx.doi. org/10.1002/(SICI)1097-0274(199904)35:4\%3C321::AIDAJIM1\%3E3.0.CO;2-L.

12. Hudson RH, Kilburn KH, Halprin GM, McKenzie W. Granulocyte recruitment to airways exposed to endotoxin aerosols. Am Rev Respir Dis. 1977;115:89-95.

13. Cavagna G, Foa V, Vigliani EC. Effects in man and rabbits of inhalation of cotton dust or extracts and purified endotoxins. Br J Ind Med. 1969;26:314-21.

14. Michel O, Nagy AM, Schroeven M, Duchateau J, Nève J, Fondu P, et al. Dose-response relationship to inhaled endotoxin in normal subjects. Am J Respir Crit Care Med. 1997;156 (4):1157-64, http://dx.doi.org/10.1164/ajrccm.156.4.97-02002.

15. Merchant JA, Lumsden JC, Kilburn KH, O'Fallon WM, Ujda JR, Germino VH, et al. Dose response studies in cotton textile workers. J Occup Med. 1973;15:222-30.

16. Rylander R, Imbus HR, Suh MW. Bacterial contamination of cotton as an indicator of respiratory effects among card room workers. Br J Ind Med. 1979;36:299-304.

17. Quirce S, Lemière C, de Blay F, del Pozo V, Gerth van Wijk R, Maestrelli P, et al. Noninvasive methods for assessment of airway inflammation in occupational settings. Allergy. 2010;65: 445-58, http://dx.doi.org/10.1111/j.1398-9995.2009.02274.x.

18. Alving K, Weitzberg E, Lundberg JM. Increased amount of nitric oxide in exhaled air of asthmatics. Eur Respir J. 1993;6:1368-70.
19. Kharitonov SA, Yates D, Robbins RA, Logan-Sinclair R, Shinebourne EA, Barnes PJ. Increased nitric oxide in exhaled air of asthmatic patients. Lancet. 1994;343:133-5, http://dx.doi.org/10.1016/S0140-6736(94)90931-8.

20. Kharitonov SA, Yates D, Springall DR, Buttery L, Polak J, Robbins RA, et al. Exhaled nitric oxide is increased in asthma. Chest. 1995;107(3 Suppl):156-7S, http://dx.doi. org/10.1378/chest.107.3_Supplement.156S.

21. Massaro AF, Gaston B, Kita D, Fanta C, Stamler JS, Drazen JM. Expired nitric oxide levels during treatment of acute asthma. Am J Respir Crit Care Med. 1995;152:800-3, http:// dx.doi.org/10.1164/ajrccm.152.2.7633745.

22. Persson MG, Zetterstrom O, Agrenius V, Ihre E, Gustafsson L. Single breath nitric oxide measurements in asthmatic patients and smokers. Lancet. 1994;343:146-7, http://dx.doi. org/10.1016/S0140-6736(94)90935-0.

23. Lund MB, Oksnel PI, Hamre R, Kongerud J. Increased nitric oxide in exhaled air: An early marker of asthma in nonsmoking aluminium potroom workers? Occup Environ Med. 2000;57:274-8, http://dx.doi.org/10.1136/oem.57.4.274.

24. Świerczyńska-Machura D, Krakowiak A, Wiszniewska M, Dudek W, Walusiak J, Pałczyński C. Exhaled nitric oxide levels after specific inahalatory challenge test in subjects with diagnosed occupational asthma. Int J Occup Med Environ Health. 2008;21:219-25, http://dx.doi.org/10.2478/v10001008-0024-x.

25. Piipari R, Piirila P, Keskinen H, Tuppurainen M, Sovijarvi A, Nordman H. Exhaled nitric oxide in specific challenge tests to assess occupational asthma. Eur Respir J. 2002;20:1532-7, http://dx.doi.org/10.1183/09031936.02.00041802.

26. Barbinova L, Baur X. Increase in exhaled nitric oxide (eNO) after work-related isocyanate exposure. Int Arch Occup Environ Health. 2006;79:387-5, http://dx.doi.org/10.1007/ s00420-005-0051-x.

27. American Thoracic Society. Modified recommended respiratory disease questionnaires for use with adults and children in epidemiological research. Washington DC: American Thoracic Society; 1978. Available from: 
http://www.thoracic.org/statements/resources/archive/ rrdquacer.pdf.

28. American Thoracic Society. ATS/ERS recommendations for standardized procedures for the online and offline measurement of exhaled lower respiratory nitric oxide and nasal nitric oxide. Am J Respir Crit Care Med. 2005;171:912-30, http://dx.doi.org/10.1164/rccm.200406-710ST.

29. American Thoracic Society. An official ATS clinical practice guideline: Interpretation of exhaled nitric oxide levels (FeNO) for clinical applications. Am J Respir Crit Care Med. 2011;184:602-15, http://dx.doi.org/10.1164/rccm.9120-11ST.

30. Miller MR, Hankinson J, Brusasco V, Burgos F, Casaburi R, Coates A, et al. Standardisation of spirometry. Eur Respir J. 2005;26(2):319-38, http://dx.doi.org/10.1183/09031936.05.00 034805 .

31. Occupational Safety and Health Administration. Occupational safety and health standards: Toxic and hazardous substances. Cotton dust [cited 2010 Sept 24]. Available from: https://www.osha.gov/pls/oshaweb/owadisp.show_document ?p_table $=$ STANDARDS $\&$ p_id $=10053$.

32. Mandryk J, Alwis KU, Hocking AD. Work-related symptoms and dose-response relationships for personal exposures and pulmonary function among woodworkers. Am J Ind Med. 1999;35:481-90, http://dx.doi.org/10.1002/(SICI)10970274(199905)35:5\%3C481::AID-AJIM5\%3E3.0.CO;2-N.

33. Sepulveda MJ, Castellan RM, Hankinson JL, Cocke JB. Acute lung function response to cotton dust in atopic and non-atopic individuals. Br J Ind Med. 1984;41:487-91.

34. Sandstrom T, Bjermer L, Rylander R. Lipopolysaccharide (LPS) inhalation in healthy subjects increases neutrophils, lymphocytes and fibronectin levels in bronchoalveolar lavage fluid. Eur Respir J. 1992;5(8):992-6.

35. Heldal KK, Madsø L, Huser PO, Eduard W. Exposure, symptoms and airway inflammation among sewage workers. Ann Agric Environ Med. 2010;17:263-8.
36. Baur X, Barbinova L. Latex allergen exposure increases exhaled nitric oxide in symptomatic healthcare workers. Eur Respir J. 2005;25:309-16, http://dx.doi.org/10.1183/0903193 6.05.00021504.

37. Moen BE, Sakwari G, Mamuya SH, Kayumba AV, Larsson L, Pehrson C, et al. Respiratory inflammation among workers exposed to airborne dust with endotoxins in a coffee curing factory 2012. J Occup Environ Med. 2012;54:847-50.

38. Sakwari G, Mamuya S, Bratveit M, Moen BE. Respiratory symptoms, exhaled nitric oxide, and lung function among workers in Tanzanian coffee factories. J Occup Environ Med. 2013;55:544-51, http://dx.doi.org/10.1097/ JOM.0b013e318285f453.

39. Mattes J, van's Gravesande KS, Moeller C, Moseler M, Brandis M, Kuehr J. Circadian variation of exhaled nitric oxide and urinary eosinophil protein $\mathrm{X}$ in asthmatic and healthy children. Pediatr Res. 2002;51(2):190-4, http:// dx.doi.org/10.1203/00006450-200202000-00011.

40. Antosova M, Bencova A, Psenkova A, Herle D, Rozborilova $\mathrm{E}$. Exhaled nitric oxide-circadian variations in healthy subjects. Eur J Med Res. 2009;14(Suppl 4):6.

41. Georges G, Bartelson BB, Martin RJ, Silkoff PE. Circadian variation in exhaled nitric oxide in nocturnal asthma. J Asthma. 1999;36:467-73, http://dx.doi.org/10. 3109/02770909909087289.

42. ten Hacken NH, van der Vaart H, van der Mark TW, Koeter GH, Postma DS. Exhaled nitric oxide is higher both at day and night in subjects with nocturnal asthma. Am J Respir Crit Care Med. 1998;158:902-7, http://dx.doi. org/10.1164/ajrccm.158.3.9712021.

43. Olin AC, Alving K, Toren K. Exhaled nitric oxide: Relation to sensitization and respiratory symptoms. Clin Exp Allergy. 2004;34:221-6, http://dx.doi.org/10.1111/j.1365-2222. 2004.01888.x.

This work is available in Open Access model and licensed under a Creative Commons Attribution-NonCommercial 3.0 Poland License - http://creativecommons.org/ licenses/by-nc/3.0/pl/deed.en. 